Published in final edited form as:

Mov Disord. 2009 January 15; 24(1): 15-24. doi:10.1002/mds.22378.

\title{
The Management of Tics
}

\author{
David Shprecher, DO and Roger Kurlan, MD*
}

\begin{abstract}
A tic is a stereotyped repetitive involuntary movement or sound, frequently preceded by premonitory sensations or urges. Most tic disorders are genetic or idiopathic in nature, possibly due to a developmental failure of inhibitory function within frontal-subcortical circuits modulating volitional movements. Currently available oral medications can reduce the severity of tics, but rarely eliminate them. Botulinum toxin injections can be effective if there are a few particularly disabling motor tics. Deep brain stimulation has been reported to be an effective treatment for the most severe cases, but remains unproven. A comprehensive evaluation accounting for secondary causes, psychosocial factors, and comorbid neuropsychiatric conditions is essential to successful treatment of tic disorders.
\end{abstract}

\section{Keywords}

Tourette's syndrome; tics; ADHD; OCD

Tics are stereotyped repetitive involuntary movements (motor tics) or sounds (vocal tics). Vocal tics, also referred to as phonic tics, are produced by the movement of air through the nose, mouth, or throat. Most individuals with tics describe a premonitory urge or sensation (such as a feeling of tension within a muscle) that improves after performing the movement. ${ }^{1}$ Tics can be voluntarily suppressed, sometimes for extended periods of time, leading to suggestion of the term "unvoluntary" movement disorder to indicate some element of conscious control. ${ }^{2}$ Motor and vocal tics are further classified as either simple or complex. Simple motor tics are single repetitive jerks. Simple vocal tics are inarticulate noises or sounds. Complex motor tics involve a sequential pattern of individual tics or more complex, coordinated actions that can resemble purposeful movements. Complex vocal tics have linguistic meaning, consisting of partial words (syllables), words, or phrases.

\section{DIFFERENTIAL DIAGNOSIS}

Simple motor tics may need to be differentiated from myoclonic jerks, which are not typically repetitive in the same body part like tics. Simple tics are commonly accompanied by complex tics and associated with premonitory sensations or suppressibility. Complex motor tics need to be distinguished from stereotypies that are longer lasting, more stereotyped movements (eg, body rocking, head nodding, and hand/wrist flapping) or sounds (eg, moaning, yelling) that occur over and over again in a more continuous, less paroxysmal fashion. Stereotypies are

\footnotetext{
*Correspondence to: Dr. Roger Kurlan, Department of Neurology, University of Rochester School of Medicine and Dentistry, 1351 Mt. Hope Avenue, Suite 100, Rochester, NY 14620. E-mail: E-mail: Roger_Kurlan@urmc.rochester.edu.

This article is part of the journal's online CME program. The CME activity including form, can be found online at http://www.movementdisorders.org/education/journalcme/

Potential conflict of interest: Dr. Shprecher has no financial conflicts of interest. Dr. Kurlan currently receives research support from Boehringer Ingelheim.

Contributor Roles: Both authors contributed to the conception, design, and writing of the manuscript. Dr. Shprecher also completed the literature search. Dr. Kurlan completed critical review and revision of the manuscript draft.
} 
typically seen in patients with autism, mental retardation, Rett syndrome, psychosis, or congenital blindness and deafness. Some tics are slow or twisting in character resembling dystonia and are termed "dystonic tics." Contrary to dystonic tics, dystonia per se tends to be slower and leads to more sustained disturbances in posture of a limb, the neck, or trunk. Compulsions frequently occur in association with tics, can sometimes be difficult to distinguish from complex motor tics, but typically differ by being done in response to an obsession, being performed to ward off future problems, or being done according to certain rules (ritualistic). 3-5

\section{CATEGORIES OF TIC DISORDERS}

\section{Primary Tic Disorders}

Chronic tics are the characteristic feature of Tourette's syndrome (TS). Diagnostic criteria include presence of both motor and vocal tics, onset in childhood, fluctuations in tic types and severity, and duration of at least one year. ${ }^{6,7}$ When chronic tics of both types cannot be identified, the terms chronic motor tic disorder and chronic vocal tic disorder are used. Tics lasting less than 1 year are termed transient tic disorder. With very high comorbidity rates of both attention deficit hyperactivity disorder (ADHD) and obsessive-compulsive disorder (OCD), TS may represent a multifaceted developmental neuropsychiatric brain disorder. 8

TS is thought to result from a developmental failure of inhibitory function within the frontalsubcortical circuits governing voluntary movements, ${ }^{9}$ possibly leading to impaired surroundoff inhibition (the ability to suppress unwanted movements). ${ }^{10}$ Dysfunction of dopamine neurotransmission is strongly implicated in this process, with current evidence pointing to low tonic synaptic dopamine levels and excessive phasic release of dopamine in the basal ganglia. 11 Some neuroimaging evidence suggests an increase in presynaptic dopamine transporters ${ }^{12-15}$ or excessive dopaminergic innervation. 16

\section{Secondary Tic Disorders}

Particularly if accompanied by other movement disorders or by other neurologic abnormalities, a secondary cause for tics should be considered. Tics often indicate the presence of a global brain developmental disorder in conditions like mental retardation, autism, and pervasive developmental disorder. Similarly, a variety of genetic and neurodegenerative conditions can cause tics, including Wilson disease, neuroacanthocytosis, 17,18 neurodegeneration with brain iron accumulation, ${ }^{19-21}$ and Huntington disease. ${ }^{22}$ Other potential causes of tics include lesions involving frontal-subcortical circuits (trauma,23 carbon monoxide poisoning, 24 hypoxic-ischemic encephalopathy, and stroke 25,26 ); central nervous system (CNS) infections (neuroborreliosis, 27 viral encephalitis 28,29 ) and CNS immune disorders (antiphospholipid antibody syndrome, ${ }^{30}$ Sydenham's chorea ${ }^{31}$ ). Tics can be a manifestation of neuroleptic drugrelated tardive dyskinesia 32 or withdrawal emergent syndrome. ${ }^{33}$ Induction or exacerbation of tics has been reported with lamotrigine, ${ }^{34,35}$ carbamazepine, ${ }^{36,37}$ cocaine, ${ }^{38-40}$ caffeine, 41 and other stimulants. 42,43

Onset of a primary tic disorder in adulthood is rare, but can occur in those genetically predisposed. In such cases, a specific trigger (such as a stressful life event, psychiatric illness, drug exposure, or infection) as well as a childhood and/or family history of tics, ADHD, or obsessive-compulsive symptoms can usually be identified. ${ }^{44-46}$

\section{INITIAL EVALUATION}

The management of tics is made challenging by a general lack of definitive evidence to support or refute commonly used treatments. This review is drawn from a synthesis of existing research data and the authors' personal experience in this area. A thorough clinical history and 
neurologic examination are generally sufficient to screen for evidence of a secondary tic disorder, and neuroimaging or electroencephalography are usually not needed unless there are unexpected findings. A more global developmental process may be suggested by history of early neurologic insults, a delay in developmental milestones, or the occurrence of seizures. A critical aspect of the initial evaluation is to check for the presence and severity of commonly associated neuropsychiatric disorders, ADHD, and OCD. We also ask about a family history of tics, ADHD, and OCD. Mood disorders, other anxiety disorders, impulse control problems, and rage attacks should also be assessed. It is also important to know about psychosocial stressors. The important goal is to accurately define the contributors to existing problems. For example, problems with attention in school could be related to ADHD, medication side effects, mental fatigue caused by efforts to suppress tics, obsessive thinking, anxiety, depression, or a learning disability. An important component of the history is to determine which symptoms are disabling (ie, causing problems in daily functioning) in order to select those target symptoms appropriate for therapy.

\section{EDUCATING THE PATIENT, FAMILY, AND SCHOOL}

Education of parents, teachers, and peers is a critical initial intervention. We inform patients and their parents that it is appropriate to tell others that they have tics, meaning that they cannot help making certain movements or sounds. We provide patients and parents with current information about the causes of tics (genetic factors, brain neurochemical imbalances) and emphasize that they are not signs of psychological or emotional illness, a common misperception. Learning about the importance of genetic factors often relieves a sense of guilt in the patient and parent. Although serious psychosocial factors can exacerbate tics, we explain how tics change in type over time and that they naturally fluctuate in severity, so it is not necessary to search for psychological problems every time their child experiences more tics. We explain the process of voluntary suppression and emphasize there is no value for anyone to point out tics to the child or tell them to stop their tics. What is needed is an open, supportive family environment in which a child can comfortably approach their parents to let them know about problematic tics or other symptoms.

A majority of TS patients experience improvement of tics in late adolescence or early adulthood. This is an important piece of information that patients and families should receive so they understand that the prognosis of TS can be quite good. We generally educate the family about the "clinical triad" (tics, ADHD, and OCD) of TS and discuss how these features relate to the patient and are often seen in relatives. We explain that the presence of tics or related symptoms per se is not a reason to initiate medication therapy or another therapeutic intervention. The key decision-making element is whether a symptom is causing significant problems in daily functioning.

Education is often needed for school personnel because there are many misperceptions of tics as being voluntary, attention-seeking, or purposely disruptive behaviors. Educating classmates may be needed and trained professionals are available in many areas to assist with this. Useful educational videos and other materials are available from the Tourette Syndrome Association (www.tsa-usa.org). Because tics can occasionally be disruptive or distract other children, we recommend that special accommodations be considered in the school setting. These might include excusing the child, at his or her request, to the nurse's office to release tics or providing additional time in a separate room when taking school tests. Such provisions are mandated in United States under laws protecting individuals with disabilities.

\section{INITIAL TREATMENT CONSIDERATIONS}

The critical first step in making treatment decisions in patients with TS is to select the most appropriate target symptoms, the ones causing the most problems in a patient's daily 
functioning. In one patient it may be the tics themselves, in another it may be comorbid ADHD or OCD and in another it may be a combination of targets. Because psychosocial stresses can worsen symptoms, it is important to probe for these and consider interventions such as individual or family counseling. For patients with mild symptoms, educational and psychological interventions may be sufficient to bring symptoms to a tolerable level of severity. Symptoms that continue to cause disability are then appropriate for medication therapy. It is important to focus on the patient's disability and not to treat just because parents find their child's tics or other symptoms to be annoying or embarrassing. Clinicians should remember that tics characteristically wax and wane in severity, so sometimes just waiting for some period of time can result in a lessening of tics and avoid medication use or increases.

\section{MEDICATIONS FOR TICS (TABLE 1)}

We generally treat tics that interfere with school or other daily activities, or are disabling because of social embarrassment, physical discomfort, or self-injury. In prescribing ticsuppressing medications, we usually titrate dosage to identify the lowest one that will result in resolution of disability. In considering the evidence supporting the efficacy of tic-suppressing drugs it is important to recognize that a substantial placebo response has been documented. ${ }^{47}$

\section{Alpha-2-agonists}

Alpha-2-agonists have moderate efficacy for tics. Although clonidine was the alpha agonist most commonly used in the past, guanfacine is now preferred because it tends to cause less sedation and can usually be dosed once (bedtime) or twice (morning, bedtime) compared with the three to four daily doses needed for clonidine. Guanfacine also tends to produce less sedation. The clonidine transdermal patch may be useful for young children who cannot swallow pills. The most common potential side effects of guanfacine include sedation, headache, dizziness, irritability, and dry mouth. We have seen a few patients who experienced syncope while treated with guanfacine. ${ }^{48}$ Alpha agonists are a particularly good choice for patients with tics and ADHD (see below), because both conditions may respond.

\section{Dopamine-Blocking Agents}

Should an alpha agonist provide insufficient benefit, we generally add or replace it with a dopamine receptor blocker. These are the most potent and predictably effective tic-suppressing medications. Classical neuroleptic antipsychotics, including haloperidol, pimozide, and fluphenazine, have documented efficacy in controlled clinical trials. These drugs fell out of favor because of frequent side effects, especially sedation, depression and mental dulling, and the introduction of the newer atypical antipsychotics. Although we tend to use an atypical antipsychotic (usually risperidone or aripiprazole) as our initial dopamine-blocking agent, they are often poorly tolerated because of sedation, weight gain, and development of the metabolic syndrome (abdominal obesity, dyslipidemia, hypertension, and impaired glucose metabolism). 49 The pendulum may be swinging back to more frequent use of classical antipsychotics, which also tend to be less expensive. Not all atypical antipsychotics have equivalent tic-suppressing effects. Risperidone ${ }^{50}$ and olanzapine ${ }^{51}$ showed efficacy in randomized controlled trials, whereas clozapine and quetiapine seem to be less effective for tics. Initial reports (and our own experience) in the use of the mixed dopamine agonist/antagonist aripiprazole have shown benefit for tics, ${ }^{52-54}$ but no controlled trials have yet been published. It should be noted that tardive dyskinesia, a feared side effect of dopamine-blocking drugs, seems to be a rare occurrence in treated TS patients, possibly due to their underlying state of altered dopamine neurotransmission. We usually prescribe a dopamine blocker in a single bedtime dose, but the dosage can be divided if needed. 


\section{Other Tic-Suppressing Drugs}

Although the usual medication treatment for tics centers on alpha agonists and antipsychotics, other types of drugs may be of benefit for patients having an inadequate response or problems with tolerability. Clonazepam has had reported modest tic-suppressing effects in published case series. ${ }^{55-57}$ This drug may be particularly useful in patients with an associated anxiety disorder. It is usually given two or three times daily, and its most common side effects are sedation and unsteadiness. The dopamine-depleting drug tetrabenazine has possible efficacy. The drug is marketed in Canada and Europe and is expected to become available soon in the United States. In an open-label study the drug showed sustained moderate to marked reduction in tics over an average of 2 years' follow-up. ${ }^{58}$ However, only $22 \%$ of subjects were free of side effects. The most common side effects are sedation, depression, insomnia, and parkinsonism. Children may tolerate higher doses of tetrabenazine than adults. ${ }^{59}$ In both age groups, the drug is usually given in two or three daily doses. Although tetrabenazine does not cause tardive phenomena, dopamine-depleting agents can cause neuroleptic malignant syndrome even after years of use. 60

Local injections of botulinum toxin can be considered when one or a few tics within the patient's repertoire are a significant source of social distress, discomfort, or self-injury. When tics have dystonic features, such as holding of a sustained neck posture or sustained eye closure, botulinum toxin may be a preferred treatment. Dramatic improvements in pain or nearblindness from such tics has been reported. ${ }^{61}$ Similar benefit has been reported for cervical tics associated with myelopathy ${ }^{62}$ or laryngeal injections for severe vocal tics ${ }^{63,64}$ including copralalia. ${ }^{65}$ Many patients treated with botulinum toxin report a lessening or disappearance of their urges to tic or in their premonitory sensations in the sites injected. Botulinum may modify sensory feedback (such as from intrafusal muscle fibers) perpetuating processes involved in tic reinforcement. Only one randomized trial with botulinum toxin for tics has been reported. ${ }^{66}$ Two weeks after injection, a significant reduction in number of motor tics was observed. The most common side effects of botulinum toxin injections are weakness and pain.

\section{POTENTIAL TIC-SUPPRESSING DRUGS}

Increasing knowledge about the neurochemical and neurophysiological abnormalities underlying tics has suggested rational, potentially beneficial new pharmacologic approaches. Dopamine agonists pergolide and ropinirole have been reported to improve tic severity in reported trials. 67,68 Benefit from low doses of dopamine agonists has been presumed to be mediated by presynaptic receptors in the striatum. ${ }^{69}$ However, recent data from functional MRI studies suggest that dopamine can restore faulty inhibitory function in the frontal cortex of individuals with TS. ${ }^{70,71}$ A placebo-controlled trial of the dopamine agonist pramipexole is in progress. Calcium channel antagonists may have activity at dopamine receptors, either through direct blockade or by reducing depolarization of midbrain dopamine neurons. ${ }^{72}$ Nifedipine, verapamil, and flunarizine have had individual reports of benefit, which have not been confirmed in a research trial. ${ }^{73-75}$

Antipsychotic drugs have varying effects on glutamate receptor trafficking, ${ }^{76}$ and a study of postmortem putamenal tissue suggested that a subtype of glutamate metabotropic receptor may be abnormally expressed in TS. ${ }^{77}$ Dopamine receptors in the frontal cortex, modulated by acetylcholine and glutamate, may have important inhibitory functions that oppose the prokinetic function of striatal dopamine receptors. ${ }^{71,78,79}$ Therefore, drugs which modify cholinergic neurotransmission at CNS nicotinic receptors or glutamatergic activity at N-methyl D-aspartate (NMDA) or alpha-amino-3-hydroxy-5-methyl-4-isoxazole proprionic acid (AMPA) receptors may be rational for study. Drugs of interest with activity at glutamate receptors include D-serine, D-cycloserine, sarcosine, modafanil, riluzole, memantine, and talampanel. 
Gamma-aminobutyric acid (GABA) is the primary inhibitory neurotransmitter released by the globus pallidus internus through its connections with the thalamus. Increased activity would be expected to reduce motor output and thus might reduce involuntary movements such as tics. Unfortunately, to date the studies of GABA-A and GABA-B receptor modulators (benzodiazepines, baclofen) have not produced good results. One randomized trial reported that the GABA-B agonist baclofen had benefit over placebo for TS, although most of the improvement was for perceived impairment from tics, rather than severity of the tics themselves. ${ }^{80}$ Levetiracetam is a medication of interest given its activity at GABA receptors. Although promising in open-label fashion, ${ }^{81}$ it has shown conflicting results in two randomized trials. 82,83 Other drugs known to enhance GABA activity include topiramate, tiagabine, vigabatrin, zonisamide, zolpidem, pagaclone, and ganaxolone.

Cortical 5HT-2A receptor density may be increased in TS. ${ }^{84}$ It is possible that some of the benefit for tics from the atypical antipsychotics risperidone ${ }^{50}$ and olanzapine ${ }^{51}$ is mediated, in part, by their respective 5HT-2 and 5HT-3 receptor blockade. There has been one open-label study report of benefit for tics from the 5HT-2 antagonist ketanserin, 85 and one small placebocontrolled report of benefit for the 5HT-3 antagonist ondansetron. ${ }^{86}$ Similar to the study of baclofen, the latter showed more benefit for the global quality of life ratings than for tics.

Anecdotal reports from TS patients that marijuana use ameliorates their tics may have scientific relevance given evidence that basal ganglia cannabinoid receptors modulate dopamine, glutamate, and GABA activity governing motoric output. ${ }^{87}$ Delta-9-tetrahydrocannabinol has shown promise for efficacy 88 in a small placebo-controlled crossover study. Further studies using drugs acting on cannabinoid receptors, such as dronabinol or nabilone, may be rational.

Given the 4:1 male to female predominance in $\mathrm{TS}^{89}$ and the typical peak of symptoms around puberty, ${ }^{90}$ a role for androgens has been proposed. ${ }^{91,92}$ Mild tic reduction was reported for the androgen blocker flutamide in a placebo-controlled crossover trial. Finasteride had dramatic benefit reported for one case of neuroleptic-refractory TS with comorbid selfinjurious tics and compulsions. ${ }^{93}$

\section{NON-PHARMACOLOGIC TREATMENTS FOR TICS}

\section{Behavioral Therapies}

In our experience, behavioral therapies have not been particularly beneficial for patients with disabling tics. Behavioral approaches have included operant conditioning models (rewarding tic suppression and discouraging disruptive tics) and massed practice (repeated, voluntarily performance of a tic until fatigue occurs). Habit reversal therapy (HRT) can be considered if a single tic (or small subset of tics) is unduly disruptive or causing self-injury or pain. HRT trains patients to recognize their tics, and to perform a volitional movement different from the tic each time a problem tic occurs. Open-label assessments have identified sustained benefit from HRT for up to 10 months. ${ }^{94}$ Current trials will include raters blinded to treatment assignment (lacking in previous trials).

\section{Transcranial Magnetic Stimulation}

Though initial studies were negative, 95,96 there have been more recent open-label reports of tic reduction following transcranial magnetic stimulation (TMS) of the supplementary motor area. ${ }^{97,98}$ A sham-controlled study of TMS for medication refractory or self-injurious tics has recently begun. 


\section{Deep Brain Stimulation Surgery}

A growing body of literature suggests that deep brain stimulation surgery (DBS), an approach currently used to treat other movement disorders including tremor, dystonia, and Parkinson's disease, may be effective for selected patients with severe, disabling, medication-refractory tics. To date, most reported cases have involved bilateral targeting of the centro-median parafascicular and ventralis oralis complex (central nuclei) of the thalamus. ${ }^{99-102}$ There have also been reports of benefit using other DBS targets, including the globus pallidus internus ${ }^{103}-108$ and nucleus accumbens/anterior limb of the internal capsule. ${ }^{109}$ Some studies have included blinded assessments in the "stimulator on" and "stimulator off" states and have identified significant reduction in tic severity. ${ }^{101,104}$ Complications of subdural hematoma, altered libido, fatigue, mood swings, weight loss, psychosis, and poor wound healing have been reported. ${ }^{99,101,102,104,110}$ Sustained benefit has been reported to at least 17 months, though most patients continue to require some medication for tics. ${ }^{99}$ Proper subject selection criteria, the best DBS target, the effect of DBS on comorbid conditions like OCD and ADHD, the long-term benefits and tolerability remain to be determined for this approach. At least one patient treated with DBS was unable to tolerate this treatment because of self-induced damage to the equipment and infection related to constant picking at the operative sites. More careful investigation of the efficacy, safety, and tolerability of DBS for the treatment of tics is needed.

\section{TREATMENT OF TICS ASSOCIATED WITH STREPTOCOCCAL INFECTION}

The "Pediatric Autoimmune Neuropsychiatric Disorders Associated with Streptococcal Infection (PANDAS)" hypothesis suggested that chronic, recurrent tics and OCD can arise as an autoimmune sequela of infection with group A beta-hemolytic streptococcus. ${ }^{111}$ In our opinion, there is insufficient evidence to conclude that streptococcal infection has a true etiological role in causing tics. We recommend that children with documented streptococcal infections be treated with an appropriate course of antibiotics, but that treatment with chronic antibiotics or immune-modifying therapies like plasma exchange or intravenous immune globulin are not justified based on existing evidence.

\section{TREATMENT OF SECONDARY TIC DISORDERS}

Tic disorders secondary to CNS lesions or infection have been reported to improve with antipsychotic drug therapy. ${ }^{26,28}$ Tics are not commonly a disabling feature of neurodegenerative diseases such as Huntington's disease, and antipsychotics have the potential to worsen overall motor function. Risk of side effects must be weighed carefully against potential benefits in deciding whether to use a drug to treat secondary forms of tics. Of course, the main target of therapy is the primary illness itself. In patients with tardive phenomena including tics, discontinuation of the offending agent is suggested as first-line treatment, and improvement can be attained with use of clonazepam, an alpha-2-agonist, clozapine, or reintroduction of an anti-psychotic. ${ }^{112,113}$ When tics occur in a withdrawal emergent fashion, antipsychotics can be resumed and weaned at a more gradual rate.

\section{TREATMENT OF ADHD (TABLE 2)}

Children and adolescents with ADHD that impairs learning should receive appropriate accommodations in the school setting. These often include preferential classroom seating, extra time for tests, an opportunity to take tests in a separate quiet room, and assistance with organizing schoolwork. An alpha-2-agonist, such as guanfacine, is a good first choice medication for patients experiencing problematic tics and ADHD because this type of drug can improve both conditions. For patients with ADHD that responds inadequately, another option is the use of the norepinephrine reuptake inhibitor atomoxetine. This drug has documented 
efficacy for ADHD and has been associated with either no change or a slight reduction in tics.

114 For patients with ongoing disabling ADHD, there is no established reason to avoid the use of stimulant medications despite the warnings provided by manufacturers. Such warnings originated decades ago and are based on very limited information. In our experience, stimulants remain the most potent and most predictably effective medications for treating ADHD in children with tics and they are well tolerated by the majority of patients. It does seem that upon initiation of therapy stimulants can worsen tics in some patients, but this effect is temporary and tic severity usually returns to baseline (or even declines from baseline) within a few weeks. The efficacy and good tolerability of the stimulant methylphenidate in children with tics has been well documented in placebo-controlled trials. ${ }^{47,115}$ Although there is insufficient evidence to say definitively, methylphenidate may be less likely to exacerbate tics than some other stimulant preparations, such as mixed amphetamine salts and dextroamphetamine. ${ }^{116}$

We have found that the newer extended release preparations of methylphenidate tend to provide good coverage of ADHD during the school day and have been very well tolerated by patients with tics. Supplemental use of short-acting methylphenidate formulations can be useful, particularly for college students who have unpredictable study hours. The most common stimulant side effects include reduced appetite, weight loss, upset stomach, headache, and insomnia.

\section{TREATMENT OF OCD (TABLE 3)}

Associated OCD can be more disabling than the tics themselves and may create a state of tension and anxiety that heightens tic severity. Cognitive behavioral therapy performed by a well-trained and experienced therapist can be a very effective nonpharmacological treatment for OCD. Selective serotonin reuptake inhibitors (SSRIs) are considered the first-line medications for OCD. The most common side effects of SSRIs are nausea, sedation, appetite change, and sexual dysfunction. Combination with an atypical antipsychotic may be helpful for cases resistant to an SSRI alone. DBS involving the internal capsule/nucleus accumbens is under investigation as a therapy more severe, medication-refractory cases of OCD.

We have found the book "Teaching the Tiger" (new edition title "Tigers, Too") by Dornbush and Pruitt to be an extremely informative reference guide to patients, parents, and teachers, because it clearly outlines many home and school psychoeducational modifications and interventions that may be effective for children with tics, ADHD, and OCD. The Tourette Syndrome Association (www.tsa-usa.org) is also a good source of educational materials. There are local support groups in many cities that can provide information, guidance, and support.

\section{CONCLUSION}

The optimum management of patients with tics involves a comprehensive approach that focuses not only on the tics themselves, but also on neuropsychiatric comorbidities (particularly ADHD and OCD) and existing psychosocial stressors. For young patients, major goals of treatment include helping the child to develop self-confidence, personal resilience, and positive psychosocial skills. A critical goal is to reduce obstacles to successful learning and socialization. The ultimate management usually requires a spectrum of interventions that may include education, cognitive-behavioral therapies, counseling, and medications. DBS might prove to be a useful therapy for patients with severe, disabling tics, or OCD.

\section{References}

1. Leckman JF, Walker DE, Cohen DJ. Premonitory urges in Tourette's syndrome. Am J Psychiatry 1993;150:98-102. [PubMed: 8417589]

2. Jankovic J. Tourette syndrome. Phenomenology and classification of tics. Neurol Clin 1997;15:267275. [PubMed: 9115460] 
3. Kurlan R, Como PG, Miller B, et al. The behavioral spectrum of tic disorders: a community-based study. Neurology 2002;59:414-420. [PubMed: 12177376]

4. Mansueto CS, Keuler DJ. Tic or compulsion?: it's Tourettic OCD. Behav Modif 2005;29:784-799. [PubMed: 16046664]

5. Robertson MM. Tourette syndrome, associated conditions and the complexities of treatment. Brain 2000;123(pt 3):425-462. [PubMed: 10686169]

6. The Tourette Syndrome Classification Study Group. Definitions and classification of tic disorders. Arch Neurol 1993;50:1013-1016. [PubMed: 8215958]

7. American Psychiatric Association. Diagnostic and statistical manual of mental disorders: DSM-IVTR. Washington DC: American Psychiatric Press Inc; 2000.

8. Palumbo D, Maughan A, Kurlan R. Hypothesis III. Tourette syndrome is only one of several causes of a developmental basal ganglia syndrome. Arch Neurol 1997;54:475-483. [PubMed: 9109750]

9. Singer HS. Tourette's syndrome: from behaviour to biology. Lancet Neurol 2005;4:149-159. [PubMed: 15721825]

10. Mink JW. Basal ganglia dysfunction in Tourette's syndrome: a new hypothesis. Pediatr Neurol 2001;25:190-198. [PubMed: 11587872]

11. Wong DF, Brasic JR, Singer HS, et al. Mechanisms of dopaminergic and serotonergic neurotransmission in Tourette syndrome: clues from an in vivo neurochemistry study with PET. Neuropsychopharmacology 2008;33:1239-1251. [PubMed: 17987065]

12. Malison RT, McDougle CJ, van Dyck CH, et al. [123I]beta-CIT SPECT imaging of striatal dopamine transporter binding in Tourette's disorder. Am J Psychiatry 1995;152:1359-1361. [PubMed: 7653693]

13. Muller-Vahl KR, Berding G, Brucke T, et al. Dopamine transporter binding in Gilles de la Tourette syndrome. J Neurol 2000;247:514-520. [PubMed: 10993492]

14. Serra-Mestres J, Ring HA, Costa DC, et al. Dopamine transporter binding in Gilles de la Tourette syndrome: a [123I]FP-CIT/SPECT study. Acta Psychiatr Scand 2004;109:140-146. [PubMed: 14725596]

15. Cheon KA, Ryu YH, Namkoong K, Kim CH, Kim JJ, Lee JD. Dopamine transporter density of the basal ganglia assessed with [123I]IPT SPECT in drug-naive children with Tourette's disorder. Psychiatry Res 2004;130:85-95. [PubMed: 14972371]

16. Albin RL, Koeppe RA, Bohnen NI, et al. Increased ventral striatal monoaminergic innervation in Tourette syndrome. Neurology 2003;61:310-315. [PubMed: 12913189]

17. Ruiz-Sandoval JL, Garcia-Navarro V, Chiquete E, et al. Choreoacanthocytosis in a Mexican family. Arch Neurol 2007;64:1661-1664. [PubMed: 17998451]

18. Hardie RJ, Pullon HW, Harding AE, et al. Neuroacanthocytosis. A clinical, haematological and pathological study of 19 cases. Brain 1991;114 (pt 1A):13-49. [PubMed: 1998879]

19. Scarano V, Pellecchia MT, Filla A, Barone P. Hallervorden-Spatz syndrome resembling a typical Tourette syndrome. Mov Disord 2002;17:618-620. [PubMed: 12112223]

20. Pellecchia MT, Valente EM, Cif L, et al. The diverse phenotype and genotype of pantothenate kinaseassociated neurodegeneration. Neurology 2005;64:1810-1812. [PubMed: 15911822]

21. Nardocci N, Rumi V, Combi ML, Angelini L, Mirabile D, Bruzzone MG. Complex tics, stereotypies, and compulsive behavior as clinical presentation of a juvenile progressive dystonia suggestive of Hallervorden-Spatz disease. Mov Disord 1994;9:369-371. [PubMed: 8041384]

22. Angelini L, Sgro V, Erba A, Merello S, Lanzi G, Nardocci N. Tourettism as clinical presentation of Huntington's disease with onset in childhood. Ital J Neurol Sci 1998;19:383-385. [PubMed: 10935835]

23. Krauss JK, Jankovic J. Tics secondary to craniocerebral trauma. Mov Disord 1997;12:776-782. [PubMed: 9380066]

24. Pulst SM, Walshe TM, Romero JA. Carbon monoxide poisoning with features of Gilles de la Tourette's syndrome. Arch Neurol 1983;40:443-444. [PubMed: 6574730]

25. Kwak CH, Jankovic J. Tourettism and dystonia after subcortical stroke. Mov Disord 2002;17:821825. [PubMed: 12210884] 
26. Gomis M, Puente V, Pont-Sunyer C, Oliveras C, Roquer J. Adult onset simple phonic tic after caudate stroke. Mov Disord 2008;23:765-766. [PubMed: 18265017]

27. Riedel M, Straube A, Schwarz MJ, Wilske B, Muller N. Lyme disease presenting as Tourette's syndrome. Lancet 1998;351:418-419. [PubMed: 9482302]

28. Northam RS, Singer HS. Postencephalitic acquired Tourette-like syndrome in a child. Neurology 1991;41:592-593. [PubMed: 1849241]

29. Dale RC, Church AJ, Heyman I. Striatal encephalitis after varicella zoster infection complicated by Tourettism. Mov Disord 2003;18:1554-1556. [PubMed: 14673900]

30. Martino D, Chew NK, Mir P, Edwards MJ, Quinn NP, Bhatia KP. Atypical movement disorders in antiphospholipid syndrome. Mov Disord 2006;21:944-949. [PubMed: 16538618]

31. Moore DP. Neuropsychiatric aspects of Sydenham's chorea: a comprehensive review. J Clin Psychiatry 1996;57:407-414. [PubMed: 9746449]

32. Bharucha KJ, Sethi KD. Tardive tourettism after exposure to neuroleptic therapy. Mov Disord 1995;10:791-793. [PubMed: 8749999]

33. Polizos P, Engelhardt DM, Hoffman SP, Waizer J. Neurological consequences of psychotropic drug withdrawal in schizophrenic children. J Autism Child Schizophr 1973;3:247-253. [PubMed: 4800390]

34. Sotero de Menezes MA, Rho JM, Murphy P, Cheyette S. Lamotrigine-induced tic disorder: report of five pediatric cases. Epilepsia 2000;41:862-867. [PubMed: 10897158]

35. Lombroso CT. Lamotrigine-induced tourettism. Neurology 1999;52:1191-1194. [PubMed: 10214742]

36. Neglia JP, Glaze DG, Zion TE. Tics and vocalizations in children treated with carbamazepine. Pediatrics 1984;73:841-844. [PubMed: 6587312]

37. Kurlan R, Kersun J, Behr J, et al. Carbamazepine-induced tics. Clin Neuropharmacol 1989;12:298302. [PubMed: 2529963]

38. Pascual-Leone A, Dhuna A. Cocaine-associated multifocal tics. Neurology 1990;40:999-1000. [PubMed: 2345623]

39. Cardoso FE, Jankovic J. Cocaine-related movement disorders. Mov Disord 1993;8:175-178. [PubMed: 8474485]

40. Daniels J, Baker DG, Norman AB. Cocaine-induced tics in untreated Tourette's syndrome. Am J Psychiatry 1996;153:965. [PubMed: 8659625]

41. Davis RE, Osorio I. Childhood caffeine tic syndrome. Pediatrics 1998;101:E4. [PubMed: 9606246]

42. Denckla MB, Bemporad JR, MacKay MC. Tics following methylphenidate administration. A report of 20 cases. JAMA 1976;235:1349-1351. [PubMed: 1061848]

43. Lowe TL, Cohen DJ, Detlor J, Kremenitzer MW, Shaywitz BA. Stimulant medications precipitate Tourette's syndrome. JAMA 1982;247:1729-1731. [PubMed: 6950128]

44. Edwards MJ, Dale RC, Church AJ, et al. Adult-onset tic disorder, motor stereotypies, and behavioural disturbance associated with antibasal ganglia antibodies. Mov Disord 2004;19:1190-1196. [PubMed: 15390017]

45. Eapen V, Lees AJ, Lakke JP, Trimble MR, Robertson MM. Adult-onset tic disorders. Mov Disord 2002;17:735-740. [PubMed: 12210863]

46. Chouinard S, Ford B. Adult onset tic disorders. J Neurol Neurosurg Psychiatry 2000;68:738-743. [PubMed: 10811697]

47. Tourette's Syndrome Study Group. Treatment of ADHD in children with tics: a randomized controlled trial. Neurology 2002;58:527-536. [PubMed: 11865128]

48. King A, Harris P, Fritzell J, Kurlan R. Syncope in children with Tourette's syndrome treated with guanfacine. Mov Disord 2006;21:419-420. [PubMed: 16229000]

49. De Hert M, Schreurs V, Sweers K, et al. Typical and atypical anti-psychotics differentially affect long-term incidence rates of the metabolic syndrome in first-episode patients with schizophrenia: a retrospective chart review. Schizophr Res 2008;101:295-303. [PubMed: 18299188]

50. Gilbert DL, Batterson JR, Sethuraman G, Sallee FR. Tic reduction with risperidone versus pimozide in a randomized, double-blind, crossover trial. J Am Acad Child Adolesc Psychiatry 2004;43:206214. [PubMed: 14726728] 
51. Onofrj M, Paci C, D’ Andreamatteo G, Toma L. Olanzapine in severe Gilles de la Tourette syndrome: a 52-week double-blind cross-over study vs. low-dose pimozide. J Neurol 2000;247:443-446. [PubMed: 10929273]

52. Ben Djebara M, Worbe Y, Schupbach M, Hartmann A. Aripiprazole: a treatment for severe coprolalia in "refractory" Gilles de la Tourette syndrome. Mov Disord 2008;23:438-440. [PubMed: 18067182]

53. Yoo HK, Choi SH, Park S, Wang HR, Hong JP, Kim CY. An open-label study of the efficacy and tolerability of aripiprazole for children and adolescents with tic disorders. J Clin Psychiatry 2007;68:1088-1093. [PubMed: 17685747]

54. Davies L, Stern JS, Agrawal N, Robertson MM. A case series of patients with Tourette's syndrome in the United Kingdom treated with aripiprazole. Hum Psychopharmacol 2006;21:447-453. [PubMed: 17029306]

55. Steingard RJ, Goldberg M, Lee D, DeMaso DR. Adjunctive clonazepam treatment of tic symptoms in children with comorbid tic disorders and ADHD. J Am Acad Child Adolesc Psychiatry 1994;33:394-399. [PubMed: 8169185]

56. Gonce M, Barbeau A. Seven cases of Gilles de la tourette's syndrome: partial relief with clonazepam: a pilot study. Can J Neurol Sci 1977;4:279-283. [PubMed: 271517]

57. Troung DD, Bressman S, Shale H, Fahn S. Clonazepam, haloperidol, and clonidine in tic disorders. South Med J 1988;81:1103-1105. [PubMed: 3047878]

58. Kenney C, Jankovic J. Tetrabenazine in the treatment of hyperkinetic movement disorders. Expert Rev Neurother 2006;6:7-17. [PubMed: 16466307]

59. Jain S, Greene PE, Frucht SJ. Tetrabenazine therapy of pediatric hyperkinetic movement disorders. Mov Disord 2006;21:1966-1972. [PubMed: 16958131]

60. Petzinger GM, Bressman SB. A case of tetrabenazine-induced neuroleptic malignant syndrome after prolonged treatment. Mov Disord 1997;12:246-248. [PubMed: 9087987]

61. Jankovic J. Botulinum toxin in the treatment of dystonic tics. Mov Disord 1994;9:347-349. [PubMed: 8041378]

62. Gironell A. [Therapeutical strategies for essential tremor]. Med Clin (Barc) 2007;129:632-637. [PubMed: 18001678]

63. Salloway S, Stewart CF, Israeli L, et al. Botulinum toxin for refractory vocal tics. Mov Disord 1996;11:746-748. [PubMed: 8914108]

64. Trimble MR, Whurr R, Brookes G, Robertson MM. Vocal tics in Gilles de la Tourette syndrome treated with botulinum toxin injections. Mov Disord 1998;13:617-619. [PubMed: 9613771]

65. Scott BL, Jankovic J, Donovan DT. Botulinum toxin injection into vocal cord in the treatment of malignant coprolalia associated with Tourette's syndrome. Mov Disord 1996;11:431-433. [PubMed: 8813224]

66. Marras C, Andrews D, Sime E, Lang AE. Botulinum toxin for simple motor tics: a randomized, double-blind, controlled clinical trial. Neurology 2001;56:605-610. [PubMed: 11245710]

67. Gilbert DL, Sethuraman G, Sine L, Peters S, Sallee FR. Tourette's syndrome improvement with pergolide in a randomized, double-blind, crossover trial. Neurology 2000;54:1310-1315. [PubMed: 10746603]

68. Gilbert DL, Dure L, Sethuraman G, Raab D, Lane J, Sallee FR. Tic reduction with pergolide in a randomized controlled trial in children. Neurology 2003;60:606-611. [PubMed: 12601100]

69. Anca MH, Giladi N, Korczyn AD. Ropinirole in Gilles de la Tourette syndrome. Neurology 2004;62:1626-1627. [PubMed: 15136698]

70. Hershey T, Black KJ, Hartlein JM, et al. Cognitive-pharmacologic functional magnetic resonance imaging in tourette syndrome: a pilot study. Biol Psychiatry 2004;55:916-925. [PubMed: 15110735]

71. Orth M, Amann B, Robertson MM, Rothwell JC. Excitability of motor cortex inhibitory circuits in Tourette syndrome before and after single dose nicotine. Brain 2005;128:1292-1300. [PubMed: 15774505]

72. Marinelli M, Rudick CN, Hu XT, White FJ. Excitability of dopamine neurons: modulation and physiological consequences. CNS Neurol Disord Drug Targets 2006;5:79-97. [PubMed: 16613555]

73. Alessi NE, Walden M, Hsieh PS. Nifedipine-haloperidol combination in the treatment of Gilles de la Tourette's syndrome: a case study. J Clin Psychiatry 1989;50:103-104. [PubMed: 2925592] 
74. Micheli F, Gatto M, Lekhuniec E, et al. Treatment of Tourette's syndrome with calcium antagonists. Clin Neuropharmacol 1990;13:77-83. [PubMed: 2306750]

75. Walsh TL, Lavenstein B, Licamele WL, Bronheim S, O'Leary J. Calcium antagonists in the treatment of Tourette's disorder. Am J Psychiatry 1986;143:1467-1468. [PubMed: 3465244]

76. Del'guidice T, Beaulieu JM. Messing up with traffic: different effects of antipsychotic agents on glutamate receptor complexes in vivo. Mol Pharmacol 2008;73:1339-1342. [PubMed: 18314495]

77. Tan EK, Lee SS, Fook-Chong S, Lum SY. Evidence of increased odds of essential tremor in Parkinson's disease. Mov Disord 2008;23:993-997. [PubMed: 18383536]

78. Hershey T, Black KJ, Hartlein J, et al. Dopaminergic modulation of response inhibition: an fMRI study. Brain Res Cogn Brain Res 2004;20:438-448. [PubMed: 15268921]

79. Drew AE, Derbez AE, Werling LL. Nicotinic receptor-mediated regulation of dopamine transporter activity in rat prefrontal cortex. Synapse 2000;38:10-16. [PubMed: 10941136]

80. Singer HS, Wendlandt J, Krieger M, Giuliano J. Baclofen treatment in Tourette syndrome: a doubleblind, placebo-controlled, crossover trial. Neurology 2001;56:599-604. [PubMed: 11245709]

81. Awaad Y, Michon AM, Minarik S. Use of levetiracetam to treat tics in children and adolescents with Tourette syndrome. Mov Disord 2005;20:714-718. [PubMed: 15704204]

82. Smith-Hicks CL, Bridges DD, Paynter NP, Singer HS. A double blind randomized placebo control trial of levetiracetam in Tourette syndrome. Mov Disord 2007;22:1764-1770. [PubMed: 17566124]

83. Awaad Y. Double-blind placebo randomized study of using levetiracetam to treat tics in children and adolescents with Tourette syndrome. Mov Disord 2008;23:S143-S144.

84. Haugbol S, Pinborg LH, Regeur L, et al. Cerebral 5-HT2A receptor binding is increased in patients with Tourette's syndrome. Int J Neuropsychopharmacol 2007;10:245-252. [PubMed: 16945163]

85. Bonnier C, Nassogne MC, Evrard P. Ketanserin treatment of Tourette's syndrome in children. Am J Psychiatry 1999;156:1122-1123. [PubMed: 10401479]

86. Toren P, Weizman A, Ratner S, Cohen D, Laor N. Ondansetron treatment in Tourette's disorder: a 3-week, randomized, double-blind, placebo-controlled study. J Clin Psychiatry 2005;66:499-503. [PubMed: 15816793]

87. Benarroch E. Endocannabinoids in basal ganglia circuits: implications for Parkinson disease. Neurology 2007;69:306-309. [PubMed: 17636069]

88. Muller-Vahl KR, Schneider U, Prevedel H, et al. Delta 9-tetra-hydrocannabinol (THC) is effective in the treatment of tics in Tourette syndrome: a 6-week randomized trial. J Clin Psychiatry 2003;64:459-465. [PubMed: 12716250]

89. Freeman RD, Fast DK, Burd L, Kerbeshian J, Robertson MM, Sandor P. An international perspective on Tourette syndrome: selected findings from 3,500 individuals in 22 countries. Dev Med Child Neurol 2000;42:436-447. [PubMed: 10972415]

90. Bloch MH, Peterson BS, Scahill L, et al. Adulthood outcome of tic and obsessive-compulsive symptom severity in children with Tourette syndrome. Arch Pediatr Adolesc Med 2006;160:65-69. [PubMed: 16389213]

91. Peterson BS, Leckman JF, Scahill L, et al. Steroid hormones and Tourette's syndrome: early experience with antiandrogen therapy. J Clin Psychopharmacol 1994;14:131-135. [PubMed: 8195454]

92. Kurlan R. The pathogenesis of Tourette's syndrome. A possible role for hormonal and excitatory neurotransmitter influences in brain development. Arch Neurol 1992;49:874-876. [PubMed: 1355964]

93. Bortolato M, Muroni A, Marrosu F. Treatment of Tourette's syndrome with finasteride. Am J Psychiatry 2007;164:1914-1915. [PubMed: 18056252]

94. Wilhelm S, Deckersbach T, Coffey BJ, Bohne A, Peterson AL, Baer L. Habit reversal versus supportive psychotherapy for Tourette's disorder: a randomized controlled trial. Am J Psychiatry 2003;160:1175-1177. [PubMed: 12777279]

95. Munchau A, Bloem BR, Thilo KV, Trimble MR, Rothwell JC, Robertson MM. Repetitive transcranial magnetic stimulation for Tourette syndrome. Neurology 2002;59:1789-1791. [PubMed: 12473773] 
96. Orth M, Kirby R, Richardson MP, et al. Subthreshold rTMS over pre-motor cortex has no effect on tics in patients with Gilles de la Tourette syndrome. Clin Neurophysiol 2005;116:764-768. [PubMed: 15792884]

97. Mantovani A, Lisanby SH, Pieraccini F, Ulivelli M, Castrogiovanni P, Rossi S. Repetitive transcranial magnetic stimulation (rTMS) in the treatment of obsessive-compulsive disorder (OCD) and Tourette's syndrome (TS). Int J Neuropsychopharmacol 2006;9:95-100. [PubMed: 15982444]

98. Mantovani A, Leckman JF, Grantz H, King RA, Sporn AL, Lisanby SH. Repetitive transcranial magnetic stimulation of the supplementary motor area in the treatment of Tourette syndrome: report of two cases. Clin Neurophysiol 2007;118:2314-2315. [PubMed: 17709291]

99. Servello D, Porta M, Sassi M, Brambilla A, Robertson MM. Deep brain stimulation in 18 patients with severe Gilles de la Tourette syndrome refractory to treatment: the surgery and stimulation. J Neurol Neurosurg Psychiatry 2008;79:136-142. [PubMed: 17846115]

100. Bajwa RJ, de Lotbiniere AJ, King RA, et al. Deep brain stimulation in Tourette's syndrome. Mov Disord 2007;22:1346-1350. [PubMed: 17580320]

101. Maciunas RJ, Maddux BN, Riley DE, et al. Prospective randomized double-blind trial of bilateral thalamic deep brain stimulation in adults with Tourette syndrome. J Neurosurg 2007;107:10041014. [PubMed: 17977274]

102. Visser-Vandewalle V. DBS in tourette syndrome: rationale, current status and future prospects. Acta Neurochir Suppl 2007;97:215-222. [PubMed: 17691307]

103. Diederich NJ, Kalteis K, Stamenkovic M, Pieri V, Alesch F. Efficient internal pallidal stimulation in Gilles de la Tourette syndrome: a case report. Mov Disord 2005;20:1496-1499. [PubMed: 16037913]

104. Ackermans L, Temel Y, Cath D, et al. Deep brain stimulation in Tourette's syndrome: two targets? Mov Disord 2006;21:709-713. [PubMed: 16463374]

105. Shahed J, Poysky J, Kenney C, Simpson R, Jankovic J. GPi deep brain stimulation for Tourette syndrome improves tics and psychiatric comorbidities. Neurology 2007;68:159-160. [PubMed: 17210901]

106. Gallagher CL, Garell PC, Montgomery EB Jr. Hemi tics and deep brain stimulation. Neurology 2006;66:E12. [PubMed: 16476922]

107. Welter ML, Mallet L, Houeto JL, et al. Internal pallidal and thalamic stimulation in patients with Tourette syndrome. Arch Neurol 2008;65:952-957. [PubMed: 18625864]

108. Dehning S, Mehrkens JH, Muller N, Botzel K. Therapy-refractory Tourette syndrome: beneficial outcome with globus pallidus internus deep brain stimulation. Mov Disord 2008;23:1300-1302. [PubMed: 18528896]

109. Flaherty AW, Williams ZM, Amirnovin R, et al. Deep brain stimulation of the anterior internal capsule for the treatment of Tourette syndrome: technical case report. Neurosurgery 2005;57:E403. [PubMed: 16234657]discussion E403

110. Houeto JL, Karachi C, Mallet L, et al. Tourette's syndrome and deep brain stimulation. J Neurol Neurosurg Psychiatry 2005;76:992-995. [PubMed: 15965209]

111. Swedo SE, Leonard HL, Garvey M, et al. Pediatric autoimmune neuropsychiatric disorders associated with streptococcal infections: clinical description of the first 50 cases. Am J Psychiatry 1998;155:264-271. [PubMed: 9464208]

112. Jaffe E, Tremeau F, Sharif Z, Reider R. Clozapine in tardive Tourette syndrome. Biol Psychiatry 1995;38:196-197. [PubMed: 7578666]

113. Reid SD. Neuroleptic-induced tardive Tourette treated with clonazepam: a case report and literature review. Clin Neuropharmacol 2004;27:101-104. [PubMed: 15190229]

114. Allen AJ, Kurlan RM, Gilbert DL, et al. Atomoxetine treatment in children and adolescents with ADHD and comorbid tic disorders. Neurology 2005;65:1941-1949. [PubMed: 16380617]

115. Gadow KD, Sverd J, Nolan EE, Sprafkin J, Schneider J. Immediate-release methylphenidate for ADHD in children with comorbid chronic multiple tic disorder. J Am Acad Child Adolesc Psychiatry 2007;46:840-848. [PubMed: 17581448]

116. Castellanos FX, Giedd JN, Elia J, et al. Controlled stimulant treatment of ADHD and comorbid Tourette's syndrome: effects of stimulant and dose. J Am Acad Child Adolesc Psychiatry 1997;36:589-596. [PubMed: 9136492] 
TABLE 1

Tic-suppressing medications

\begin{tabular}{|c|c|c|}
\hline Generic name & How supplied & Daily dose (mg) \\
\hline \multicolumn{3}{|l|}{ Alpha agonists } \\
\hline Clonidine & Tablets: $0.1,0.2,0.3 \mathrm{mg}$. Transdermal: $0.1,0.2,0.3 \mathrm{mg} / \mathrm{d}$ & $0.05-0.5$ \\
\hline Guanfacine & Tablets: $1,2 \mathrm{mg}$ & $0.5-4$ \\
\hline \multicolumn{3}{|l|}{ Antipsychotics } \\
\hline Risperidone & Tablets: 1, 2, 3, $4 \mathrm{mg}$. Oral solution: $1 \mathrm{mg} / \mathrm{mL}$ & $0.5-16$ \\
\hline Aripiprazole & Tablets: 5, 10, 15, 20, $30 \mathrm{mg}$. Oral solution: $1 \mathrm{mg} / \mathrm{mL}$ & $5-30$ \\
\hline Haloperidol & Tablets: $0.5,1,2,5,10,20 \mathrm{mg}$. Oral solution: $2 \mathrm{mg} / \mathrm{mL}$ & $0.5-20$ \\
\hline Pimozide & Tablets: $1,2 \mathrm{mg}$ & $0.5-10$ \\
\hline Fluphenazine & Tablets: $1,2.5,5,10 \mathrm{mg}$ & $0.5-20$ \\
\hline \multicolumn{3}{|l|}{ Other agents } \\
\hline Clonazepam & Tablets: $0.125,0.5,1,2 \mathrm{mg}$ & $0.5-10$ \\
\hline Tetrabenazine & Tablets: $25 \mathrm{mg}$ & $25-200$ \\
\hline
\end{tabular}

For both children and adults, start with the lowest dosage. 
Medications of ADHD

TABLE 2

\begin{tabular}{llcc}
\hline Generic name & How supplied & Daily dose (mg) & Doses per day \\
\hline Atomoxetine & Capsules: $10,18,25,40,60 \mathrm{mg}$ & $10-120$ & 1 \\
Methylphenidate & Tablets: $5,10,20 \mathrm{mg}$ & $2.5-60$ & $2-4$ \\
Methylphenidate ER & Capsules: $18,27,36,54 \mathrm{mg}$ & $18-90$ & 1 \\
D-Methylphenidate & Tablets: $2.5,5,10 \mathrm{mg}$ & $2.5-20$ & $2-3$ \\
D-Methylphenidate ER & Capsules: $5,10,20 \mathrm{mg}$ & $5-40$ & 1 \\
Methylphenidate transdermal & Patch: $10,15,20,30 \mathrm{mg}$ & $10-30$ & 1 \\
D-,L-Amphetamine & Tablets: $5,7.5,10,12.5,15,20,30 \mathrm{mg}$ & $2.5-60$ & $1-2$ \\
D-,L-Amphetamine ER & Capsules: $5,10,15,20,25,30 \mathrm{mg}$ & $5-30$ & 1 \\
Dextroamphetamine & Tablets: $5 \mathrm{mg}$ & $2.5-40$ & $2-4$ \\
Dextroamphetamine ER & Capsules: $5,10,15 \mathrm{mg}$ & $5-40$ & $2-4$ \\
Lisdexamfetamine & Capsules: $30,50,70 \mathrm{mg}$ & $30-70$ & 1 \\
\end{tabular}

For both children and adults, start with the lowest dosage.

ER, extended release. 
Selective serotonin reuptake inhibitors

TABLE 3

\begin{tabular}{llc}
\hline Generic name & How supplied & Daily dose (mg) \\
\hline Clomipramine & Capsules: $25,50,75 \mathrm{mg}$ & $25-250$ \\
Citalopram & Tablets: $20,40 \mathrm{mg}$ & $10-40$ \\
Escitalopram & Tablets: $5,10,20 \mathrm{mg}$. Oral solution: $5 \mathrm{mg} / 5 \mathrm{~mL}$ & $10-20$ \\
Fluvoxamine & Tablets: $25,50,100 \mathrm{mg}$ & $25-300$ \\
Paroxetine & Tablets: $10,20,30,40 \mathrm{mg}$. Oral suspension: $10 \mathrm{mg} / 5 \mathrm{~mL}$ & $10-60$ \\
Fluoxetine & Capsules: $10,20 \mathrm{mg}$. Oral solution: $20 \mathrm{mg} / 5 \mathrm{~mL}$ & $10-60$ \\
Sertraline & Tablets: $25,50,100 \mathrm{mg}$ & $25-200$ \\
\hline
\end{tabular}

For both children and adults, start with the lowest dosage. 